\title{
The Curse of the Credit Cycle: A Theoretical Review of Potential
}

\section{Cures}

\author{
Dmitry Vladimirovich Burakov ${ }^{1}$ \\ ${ }^{1}$ Department of Monetary Relations and Monetary Policy, Financial University under the Government of \\ Russian Federation, Moscow, Russian Federation \\ Correspondence: Dmitry Vladimirovich Burakov, Department of Monetary Relations and Monetary Policy, \\ Financial University under the Government of Russian Federation, Moscow, Russian Federation. Tel: \\ 89-67-008-2725. E-mail: dbur89@yandex.ru
}

Received: January 31, 2014 Accepted: March 18, 2014 Online Published: April 29, 2014

doi:10.5539/ass.v10n10p127 URL: http://dx.doi.org/10.5539/ass.v10n10p127

\begin{abstract}
In this article, we set ourselves the task of explaining the phenomenon of the credit cycle's resilience. Some studies show that credit cyclicity is stable, at least during the last 160 years. At the same time, most of the instruments and measures used for curbing the cycle do not bring tangible and visible results. In this regard, we have set the task of systematizing the existing studies on the issue. In particular, in this paper we've analysed the potential effectiveness of various measures in the abolition of or mitigating the credit cycle. These included a change in capital requirements of commercial banks, the evolution of credit risk evaluation methods, changes in the targets of monetary policy, a degree of institutional development of the economy, a level of competitive pressure on the credit market, targets for non-performing loans, credit rationing policies. As a result of the carried out comparative theoretical research, we came to conclusion that none of the above mentioned tools is an effective medicine, which can cure the credit market from the cyclical pattern of its existence. However, the experience of Asian region, in particular the use of directed credit distribution and establishing targets on non-performing loans and loan losses significantly reduces an amplitude of the cycle, however, at the price of higher credit rationing levels.
\end{abstract}

Keywords: credit cycle, credit risk, credit market, credit rationing, monetary policy, bank capital, Basel, corruption

\section{Introduction}

Credit cyclicity along with the phenomenon of the business cycle holds the title of one of the main puzzles of the economic realm. Sustainable alternation of the periods of rise and fall in credit dynamics is a significant problem standing in the way of achieving stable development of the credit market. It is widely believed that the oscillations in credit activity are the result of credit market imperfections. The central place in the explanation of this phenomenon is often given either to interaction of bounded rationality and information asymmetry in the process of changing multiple equilibria in the credit market (Stiglitz \& Weiss, 1981; Rötheli, 2012; Burakov, 2013) or, in the framework of the shock approach, to financial accelerator and uncertainty of economic conditions (Bernanke, Gertler, \& Gilchrist, 1996; Marti, 1996; Kiyotaki-Moore, 1997). However, regardless of the approach to determining the nature of the credit cycle, resilience of its existence leaves no doubt today. Unfortunately, only a limited number of studies upon the history of credit cycles exist. (Kindleberger, 1975; Haldane, 2010) They show that, regardless of changes in the amplitude of fluctuations in credit, the duration of the cycle and the type of the shock, leading to changes in phases, this phenomenon is a stably recurrent one, at least during the last 160 years (Haldane, 2010). Various attempts to eliminate it, to curb or mitigate, one way or another, are based on a certain theoretical foundation. It is this foundation that serves as a necessary basis for the conduct of a specific monetary policy framework and for the formation of preferences for using one instrument in relation to other. The same logic holds true for the research community, which develops the necessary theoretical background for the use of these tools. However, given the diversity of approaches to the definition of fundamental theoretical principles of the credit cycle, the spread of the proposed measures is truly astonishing. Today, to achieve stability in the credit market absolutely contradictory measures are offered: from the return to the gold standard and abolishment of the fractional reserve banking system to switching monetary regimes in 
favor of credit targeting (Akerlof \& Shiller, 2009). Such fragmentation of the points of view, in our opinion, is a consequence of the above described problem of methodological pluralism. Complex researches summarizing different points of view in the modern literature, unfortunately, don't exist, due to just recent resurgence of interest in the issue of credit cyclicity. As to enrich the existing theoretical proposals for elimination of the credit cycle or mitigation of its negative externalities for the economy, we set ourselves the task to summarize the main directions of combating the credit cycle and to assess their potential efficacy for the possibility of the credit cycle's elimination.

The structure of this paper is organized as follows and includes the following sections: section 2 presents a brief summary of methodological approaches used for the analysis of credit cycle's resilience phenomena; section 3 gives an overview of existing methods for eliminating or curbing the credit cycle and also presents the analysis of them in order to determine their absolute or relative appropriateness for achieving the above mentioned goal; section 4 summarizes the results of the conducted study; section 5 presents a bibliographical list of proceeding used in the preparation and conduct of this study.

\section{Methodologies}

This study is based on the use of different research methods. These include statistical methods of research associated with identifying the correlations between variables; also comparative analysis methods in order to determine the validity of the analyzed correlation are used. Much attention in this study we pay to the historical retrospective due to the specific characted of the subject studied. In most cases, statistical time series for credit dynamics over a significant period of time are not available for most countries in the world. Constant changes in the standards for the presentation of statistical material by national statistical offices and monetary authorities, due to changes of the basis period-from a year basis to a quarter one, or from quarterly to monthly series, also greatly exacerbate the problem. Thus, in some cases, identification of the fact of cyclical movement of credit in a separate country may be based not so much on statistical time series, but rather on empirical observations and theoretical assumptions of the individual authors, studying the issue. However, we do not believe that this fact reduces the value of the analysis provided in this research.

In this work the credit cycle is defined as the change in total monthly growth rates of funds lent by commercial banks to borrowers in the real sector of an economy. The base period shall be considered as the previous month of the current year. A phase of the credit cycle is defined as sustained periods of time at which the monthly growth rates of credit lie in a certain plane. For downward phases-growth rates are negative, for upward phases-positive. In this study, we do not set ourselves the task of a detailed identification of each phase of the cycle. Rather, our task is to evaluate whether a certain method of regulation or a condition of economic (credit) system development has an effect on the cyclical pattern of credit dynamics. In case of absence of sufficient and acceptable information for the pace of credit growth, we propose to use the data on the dynamics of non-performing loans (NPL) or loan losses.

To identify positive or negative correlation between the resulting (credit cycle) and variable (e.g., type of methods of credit risk evaluation) we use the comparison of time series or methods of comparative analysis by isolating the individual periods and matching them depending on the dominant type of a variable in this period.

Given the universality of the behavioral patterns of credit market participants, in particular of bounded rationality, the presence of negative or weak positive correlations between the variables in one market ceteris paribus gives, in our opinion, a sufficient ground for extrapolating an effect to other markets.

The theoretical basis for this study is the combination of theoretical and empirical studies of various researchers on the issue of the credit cycle.

\section{Potential Remedies for the Credit Cycle: A Theoretical Review}

\subsection{Strengthening Bank Capital Requirements}

In the midst of a global financial crisis, the number of the researches devoted to tightening capital requirements in commercial banks increased dramatically. The main proponent of this idea on the world financial arena became the Basel Committee on banking supervision. Theoretical basis of this clause suggested strengthening the capacity of banks to absorb shocks occurring in the economic system. (Basel Committee, 2010). In addition to tightening capital adequacy requirements it was proposed to form countercyclical capital buffers: "airbags", softening the burst of the crisis phenomena on the one hand, and fulfilling the signaling function for banks: restraining the process of excessive credit expansion.

In addition to proposals of the Basel Committee, the paradigm of liabilities' regulation gained support in the writings of the research community. For example, formation of reserve capital in different variations (see e.g., 
Grossman \& Imai, 2012) will promote the intensification of monetary liability of commercial banks, thereby trapping the problem of limited liability. (Gollier, Koehl, \& Rochet, 1997; Sinn, 2001) Unfortunately, this view is based on the idea of full rationality of creditors. Some studies show that this method of dealing with the problem of limited liability, and, as a consequence, the removal of a problem of excessive credit expansion, is unlikely to bring sufficient results (Haldane, 2010). Moreover, these doubts are confirmed by historical evidence. If we turn to the analysis of dependence between the level of bank capital adequacy in retrospect, and the existence of the credit cycle, it becomes clearly visible that a direct relation between these elements is not traced. For example, in the UK during the second half of the XIX century, the capital adequacy ratio was at a significantly higher level than $50 \%$. (Grossman \& Imai, 2012) The same is true for the USA in the beginning of the XX century (Sinkey, 1997). At the same time, the research of experts of the Bank of England gives great support to the fact of existence of the credit cycle in these periods of time for both the UK and USA (Haldane, 2010).

Another line of argumentation can be found in behavioral economics field of research. For example, experimental studies show that tightening capital adequacy requirements can bring significant results only in case of frame of gains. In case of frame of losses (which is manifested in the credit market in conditions of rigid competition) a sufficient increase in the market rate of return on investments may reduce the effect of increasing the monetary liability (Burakov, 2014).

Thus, considering tightening of capital adequacy requirements as a sufficient instrument to curb the credit cycle or even eradicate it seems ambiguous.

\subsection{Improving Credit Risk Evaluation Methods}

The achievement of stability in the development of the credit market is directly connected with the management of the cyclical movement of credit. In other words, timely impact on the credit expansion will directly affect the level of credit risk taken by banking institutions. In the proposals of the Basel Committee on banking supervision, solution of this task is to be fulfilled by optimizing methods of risk evaluation. (Basel Committee, 2010). In our opinion, the use of such approach possibly cannot bring the desired effect due to the fact that the theoretical basis of the documents developed by the Committee is the paradigm of neoclassical school of economics that is not consistent with economic realities. Basel III (like previous versions) does not take into account one of the most important provisions of the modern economic theory-a notion of bounded rationality of market players, proved as viable and of practical significance.

An alternative view upon the place and role of credit risk evaluation methods of is offered by proponents of the behavioral school of Economics. The end of 1990s was a time of a vigorous debate upon the effectiveness of the application of VaR instrument for analysis of credit risk, as a promising innovation in risk management. Even today the debate is still going on. (Taleb, 2009) Support of quantitative analysis methods' ambiguity and periods of their introduction (innovations in the risk management) can be found in works of another behavioral economist T. Rötheli (2013). According to his hypothesis, introduction of new methods of credit risk analysis in USA in the beginning of the XX century, on the one hand, increased the accepted risks in the credit market, on the other acted as an anchor-factor reinforcing excessive confidence in the positive outcome of granting loans (new methods of analysis were perceived as a panacea for low-quality borrowers that time). Based on an historical analysis, Rötheli concludes that the innovations in evaluation methods have helped to increase the level of credit risk accepted by commercial banks and competition in the credit market.

Thus, there is uncertainty regarding the place and role of credit risk assessment methods in fulfilling their direct task. Supporters of the mainstream of economic thought proceed from the necessity of further development of risk evaluation methods, while supporters of the heterodox schools warn against excessive relying on the risk evaluation methods and try to recall that the decision, even using any of the methods, is made by a human whose rationality is far from full.

The answer to this ambiguity of views can be found in the comparison of the evolution of credit risk assessment methods and sustainability of oscillations in credit dynamics. (Burakov, 2013) Results of the comparison of credit dynamics, changes in loan losses for the period more than 100 years and the dominant methods of credit risk evaluation used in certain periods of analyzed time, generally support an alternative point of view according to which methods of credit risk evaluation are no significant power to cure the credit market from the cyclical pattern of its development.

\subsection{Quality of Market Institutions}

Another strand of the literature on the credit cycle's issue highlights the improvement of the quality of market institutions as a necessary condition for the achievement of stability of credit market development, and, as a 
consequence, for curbing the credit cycle. (La Porta, Lopez-de-Silanes, \& Shleifer, 2002; Barth, Caprio, \& Levine, 2006; Bertay, Demirguc-Kunt, \& Huizinga, 2012). The theoretical background of this approach is based on the presence of a tight relationship between the quality of institutions (respecting the right, fulfilling the obligations, and quality of the institutions exercising control over first and last ones) and the ability of credit institutions with high quality and timely use their rights and fulfill their obligations to the counterparties. In this case, high quality of institutions contributes to the reduction of agency costs and the increase of availability of credit, reducing the level of credit rationing, and generally improves the quality of loans granted. In the case of weak market institutions in the national economy, the risk premium on loans is growing, as well as the credit standards, set by creditors to borrowers; the credit market is narrowing, along with negative impacts on economic development. Another important consequence of poor market institutions is the widespread corruption and bribery in the framework of credit relationship, which affects credit market through a number of channels (Weill, 2011). One of the channels is affiliated lending, which leads to the satisfaction of low quality demand for credit. The consequence of this equilibrium in the credit market is in increased sensitivity to shocks and excessive acceptance of credit risks, including their high concentration.

It is believed that the developed markets with high quality institutions are less prone to cyclical crises in the credit market. (Reinhart \& Rogoff, 2011) In other words, a common point of view according to which, improvement of the quality of institutions can relieve the credit market from frictions, leading to a cyclical nature of its development.

On the other hand, studies of developing countries show that the credit cycle exists regardless of the quality of market institutions. In case of low-quality institutions amplitude of credit oscillations is higher, than in countries with high-quality ones. However, a mere acquaintance with the data of statistics gives the chance to assume that the quality of institutions affects the amplitude of oscillations, not the cycle itself. (Note 1) Credit cyclicity remains stable, in both developed and developing countries.

Therefore, the potential for institutional reforms to address the cyclical pattern of credit market development seems not to be a remedy.

\subsection{Curbing Competitive Market Forces}

Some researchers believe that competition is the driving force of the credit cycle (Birkchandan, Hirshleifer, \& Welch, 1998; Ruckes, 2004; Hauswald \& Marquez, 2006; Acharya \& Yorulmazer, 2008; Haldane, 2010). And it is by curbing the competitive pressure on credit market is possible to remove the threat of cyclical pattern of development of the credit market. The theoretical basis of this approach lies in the correlation between the competitive pressure and the level of the accepted credit risk by commercial banks. The higher competition on the credit market, the higher is the willingness of the creditors to take excessive risks, satisfying the demand for credit of lower quality borrowers. In the proof of the validity of this approach we may again appeal to the study of Haldane (2010). Historical evidence of cyclical development of credit shows that in the "Quiet Period" in the US, the amplitude of the credit cycle has declined sharply. That was mainly connected with the tightening of the regulation of banking institutions. Indeed, compressing competition is an essential tool to rein in the credit cycle.

However, assuming competition to be the driving force of the credit cycle seems premature. In the absence of competition in the credit market, in case of weak institutions, the wide spread of cartels, including state owned ones, which allocate credit, credit cycle seems to be a stable recurring phenomenon (as, for example, in case of Russia).

\subsection{Non-Performing Loans and Loan Losses Targeting}

Another direction in the management of the credit cycle can be found in the experience of the Asian countries that went another way from the European countries. Realizing the importance of the credit and its potential impact on economic development, a number of countries set a goal of targeting not inflation or monetary aggregates, but set a task of straight and directed control of the credit activity. The result of this approach was the emergence and implementation in practice, of targeting non-performing loans and loan losses mechanism. (Banerjee, Cole, \& Duflo, 2006) Theoretical basis of this mechanism is the continuous monitoring of performance of activities of the banking system of the country, associated with the results of the activities of banks. Anchoring the quality of the activity of credit organizations is manifested in controlling the growth of debt overdue and inspections in order to determine the reasons for the growth of non-performing loans' share or losses on granted loans. Moreover, given the nature of the institutional development of Asian countries (e.g., India), this supervision is also designed to determine the presence or absence of affiliation in lending funds. Such a system of incentives naturally influenced the behaviour of credit managers. The consequence of this incentive was a rise in the exerted efforts to undertake the verification of the potential credit application on the one hand, 
and tighter monitoring of borrowers, which received a loan on the other. Another consequence of this approach was a sky-rocketed increase in aversion towards losses of credit institutions (including government owned banks) in the process of meeting the demand for credit.

Indeed, the effects of this approach are ambiguous. On the one hand, for example, India has managed to achieve stability in the development of the credit market. According to the Reserve Bank of India, the amplitude of the credit dynamics is minimal, and the national economy is experiencing the same credit cycle for almost 20 years, while other countries for this period of time managed to pass through 2 or 3 cycles. On the other hand, consequences of these measures are increasing credit rationing, expressing in reducing the supply of credit and the development of the informal sector of credit market.

In our opinion, the use of this mechanism in terms of achieving stability in the development of the credit market is definitely positive. From the point of view of encouraging an economic growth, the use of this mechanism shall be in line with the goals and strategies of economic development in medium and long-term period and also shall be determined by the monetary and economic authorities of the country.

\section{Discussion and Conclusion}

In the result of the carried out research we came to conclusion, according to which eradication of cyclical pattern of credit fluctuations is impossible today. This conclusion generally confirms the hypothesis postulated in the beginning of the study. On the one hand, abolition of the cycle is hampered because of the presence of credit market imperfections, in the form of information asymmetry, and the effects that it brings to life. On the other hand, bounded rationality of market players also puts a stamp on the resilience of the credit cycle. It is also should not be forgotten about the existence of tail risks-unpredictable events, probability of which is difficult to evaluate. These features inherent in any market, including credit one, are the very inherent sources, which give birth to the oscillations in credit dynamics.

In our opinion, it is rational to assume that the question about how the credit cycle could be eradicated should not stand today. Rather we need to search for ways of its containment, for methods of controlling this phenomenon in order to ensure stable functioning of the credit market on the one hand and effective on another. A review of theoretical proposals of various researchers and monetary authorities, which we have carried out in this study, shows that a clear understanding, as well as certainty and unity in the ways for achieving these goals, today do not exist.

The key problem of the management of the credit cycle is a type of a classical dichotomy between development goals and goals of stability. And the measures for the elimination or mitigation of the credit cycle studied here are situated exactly between these theoretical pillars.

So, for example, a tightening of capital requirements does not have a substantial impact on the amplitude of fluctuations in credit. The same is true for the improvement of risk evaluation methods, as well as the economic and institutional development of the credit system. Regulation of the competitive pressure level on the credit market is, in our opinion, a promising method of control, but, unfortunately, the proposals for the use of this approach are quite vague. Moreover, the study has found that the credit cycle "feels quite comfortable" even in the absence of competition in case of poor institutional environment in a particular economy. But in case of institutionally developed markets, curbing the competitive pressure can be a very effective mechanism for achieving sustainable development.

A separate line of research, reflecting the phenomenal success in combating the credit cycle in Asian countries (India and China, for example), points out the positive effects of relying on strong and regular government interventions in the form of directed control over the allocation of credit resources, its rationing and the establishment of the NPL and loan losses based targeting regimes. As results of various researches and statistical analysis show, this approach actually helps to cure the "curse" of the credit cycle. Supporting this approach, it should be noted that the use of such experience in the 1970s, and 1980s in developed countries (in France, for example), also brought significant results. However, the price of direct interference in the mechanism of the credit market, as a rule, is quite high and reveals itself in the form of conscious suppression of the credit supply and growth of credit rationing level with all arising frictions in other markets. Although it is worth noting that an acceptable price for achieving stability in every credit (and economic) system should be determined by this system itself and this matter, in our opinion, should not be of particular interest for economic research area, until there is solid evidence of the ineffectiveness of such approaches.

Confirming the need for tighter regulation by alternative ways, we can also highlight the U.S. experience in the so-called "Quiet Period" in the credit market. Significant compression of competition between commercial and 
investment banks has contributed in achieving conservative behaviour on the credit market and avoiding systemic crises and large-scale bankruptcies during almost 30 years period, until the "Financial Liberalization" has gained strength in 1980s.

Thus, it seems obvious that taking into account the "immortality" of the credit cycle, defeating this phenomenon is not an easy task to complete, and monetary policies directed to its curbing should be in each case specific and consider the peculiarities of national economic system and features of national credit market. Unfortunately, globalization of approaches of regulating credit market in general and the banking sector in particular is hardly can contribute significantly in achieving this goal.

\section{References}

Acharya, V. V. (2009). A theory of systemic risk and design of prudential bank regulation. Journal of Financial Stability, 5(3), 224-255. http://dx.doi.org/10.1016/j.jfs.2009.02.001

Acharya, V. V., \& Yorulmazer, T. (2008). Information contagion and bank herding. Journal of Money, Credit and Banking, 40(1), 215-231. http://dx.doi.org/10.1111/j.1538-4616.2008.00110.x

Akerlof, G., \& Shiller, R. (2009). Animal spirits: How human psychology drives the economy, and why it matters for global capitalism. Princeton University Press.

Bagehot, W. (1873). Lombard Street: A description of the money market. London: Henry S. King and Co.

Banerjee, A., Cole, S., \& Duflo, E. (2006). Are the monitors over-monitored? Evidence from corruption, vigilance and lending in Indian banks. Mimeo: MIT.

Barth, J. R., Caprio, G., \& Levine, R. (2006). Rethinking bank regulation. Till Angels Govern. Cambridge University Press.

Basel Committee on Banking Supervision. (2010). Basel III: A Global Regulatory Framework for more resilient banks and banking systems. Bank for International Settlements.

Berger, A., \& Udell, G. (2004). The institutional memory hypothesis and the pro-cyclicality of bank lending behavior. Journal of Financial Intermediation, 13(4), 458-495. http://dx.doi.org/10.1016/j.jfi.2004.06.006

Bernanke, B., Gertler, M., \& Gilchrist, S. (1996). The financial accelerator and the flight to quality. The Review of Economics and Statistics, 78(1), 1-15. http://dx.doi.org/10.2307/2109844

Bertay, A. C., Demirguc-Kunt, A., \& Huizinga, A. (2012). Bank ownership and credit over the business cycle: Is lending by state banks less pro-cyclical? Policy Research Working Papers.

Birkchandan, S., Hirshleifer, D., \& Welch, I. (1998). Learning from the behavior of others: Conformity, fads, and informational cascades. Journal of Economic Perspectives, 12, 151-170. http://dx.doi.org/10.1257/jep.12.3.151

Burakov, D. V. (2013a). Do methods of estimation affect credit risk oscillations: An empirical study. Upravlenie jekonomicheskimi sistemami: Jelektronnyj nauchnyj zhurnal, 60(12). Retrieved from http://www.uecs.ru/finansi-i-kredit/item/2613-2013-12-11-12-41-35

Burakov, D. V. (2013b). Exogenous credit cycle: An experimental study. World Applied Sciences Journal, 26(6), 733-736.

Burakov, D. V. (2014a). Does framing affect risk attitude? Experimental evidence from credit market. American Journal of Applied Sciences, 11, 391-395. http://dx.doi.org/10.3844/ajassp.2014.391.395

Burakov, D. V. (2014b). Limited liability problem, bank capital and credit cycles: A behavioral economic approach. Middle East Journal of Scientific Research, 21(1), 28-32.

Fungacova, Z., Herrala, R., \& Weill, L. (2013). The influence of bank ownership on credit supply: Evidence from the recent financial crisis. Emerging Markets Review, 15, 136-147. http://dx.doi.org/10.1016/j.ememar.2013.02.002

Geanakoplos, J. (2010). The leverage cycle. NBER Macroeconomics Annual 2009, 24, 1-65. University of Chicago Press.

Glasner, D. (1997). Business cycles and depressions: An encyclopedia. Garland Publishing Inc., New York \& London.

Gollier, C., Koehl, P. F., \& Rochet, J. C. (1997). Risk-taking behavior with limited liability and risk aversion. The Journal of Risk and Insurance, 64(2), 347-370. http://dx.doi.org/10.2307/253734

Gonzales-Hermosillo, B. (1999). Determinants of ex-ante banking system distress: A macro-micro empirical exploration of some recent episodes. IMF Working Papers, 33. Washington DC. http://dx.doi.org/10.5089/9781451845167.001

Gorton, G., \& He, P. (2008). Bank credit cycles. Review of Economic Studies, 75(4), 1181-1214. http://dx.doi.org/10.1111/j.1467-937X.2008.00497.x 
Grossman, R. S., \& Imai, M. (2012). Contingent capital and bank risk-taking among British banks before the First World War. The Economic History Review, 66(1), 132-155. http://dx.doi.org/10.1111/j.1468-0289.2011.00638.x

Guttentag, J., Herring, M., \& Richard, J. (1986). Disaster myopia in international banking. Princeton University Essays in International Finance, 164.

Haldane, A. (2010). Curbing the credit cycle. Speech presented at the Columbia University Center on Capitalism and Society Annual Conference, New York.

Hauswald, R., \& Marquez, R. (2006). Competition and strategic information acquisition in credit markets. Review of Economic Studies, 19, 967-1000.

Holmstrom, B., \& Tirole, J. (1997). Financial intermediation, loanable funds, and the real sector. Quarterly Journal of Economics, 112, 663-692. http://dx.doi.org/10.1162/003355397555316

Kahneman, D., \& Tversky, A. (1979). Prospect Theory: An Analysis of Decision under Risk. Econometrical, 47(2), 263-292. http://dx.doi.org/10.2307/1914185

Kindleberger, C. (1975). Manias, panics, and crashes: A history of financial crises. Palgrave Macmillan.

Kiyotaki, N., \& Moore, J. (1997). Credit cycles. Journal of Political Economy, 105(2), 211-248. http://dx.doi.org/10.1086/262072

La Porta, R., Lopez-de-Silanes, F., \& Shleifer, A. (2002). Government ownership of banks. Journal of Finance, 57(1), 265-301. http://dx.doi.org/10.1111/1540-6261.00422

Marti, M. S. (1996). Bloodedly rational credit cycles. Economics Working Paper, 156.

Mills, J. (1867). On credit cycles and the origin of commercial panics. In T. E. Burton (Ed.), Financial crises and periods of industrial and commercial depression.

Minsky, H. (1992). The financial instability hypothesis. Working Paper No. 74, the Jerome Levy Economics Institute of Bard College.

Rajan, R. (1994). Why bank credit policies fluctuate: A theory and some evidence. Quarterly Journal of Economics, 109(2), 399-441. http://dx.doi.org/10.2307/2118468

Rothbard, M. (1962/2004). Man, economy and state (with Power and market). Auburn, Ala.: Ludwig von Mises Institute.

Rötheli, T. (2013). Innovations in US banking practices and the credit boom of the 1920s. Business History Review, 87(2), 309-327. http://dx.doi.org/10.1017/S000768051300041X

Rötheli, T. F. (2012). Bloodedly rational banks' contribution to the credit cycle. Journal of Socio-Economics, 41(5), 730-737. http://dx.doi.org/10.1016/j.socec.2012.07.005

Ruckes, M. (2004). Bank competition and credit standards. Review of Financial Studies, 17, 1073-1102. http://dx.doi.org/10.1093/rfs/hhh011

Sinkey, J. F. (1997). Commercial bank financial management. Prentice Hall College Div. (5th ed.).

Sinn, H. W. (2001). Risk taking, limited liability and the competition of bank regulators. NBER Working Paper No. 8669. NBER.

Stiglitz, J. A., \& Weiss, A. (1981). Credit rationing in markets with imperfect information. The American Economic Review, 71(3), 393-410.

Taleb, N. (2009). Report on The Risks of Financial Modeling, VaR and the Economic Breakdown. Report presented on Committee on Science, Space and Technology, 9.

Thaler, R. H. (1988). Anomalies: The Winner's Curse. Journal of Economic Perspectives, 2(1), 191-202. http://dx.doi.org/10.1257/jep.2.1.191

Weill, L. (2011). Does corruption hamper bank lending? Macro and micro evidence. Empirical Economics, 41(1), 25-42. http://dx.doi.org/10.1007/s00181-010-0393-4

\section{Note}

Note 1. See for example, statistical data on credit dynamics in Russia, Ukraine, Poland, and Bulgaria.

\section{Copyrights}

Copyright for this article is retained by the author(s), with first publication rights granted to the journal.

This is an open-access article distributed under the terms and conditions of the Creative Commons Attribution license (http://creativecommons.org/licenses/by/3.0/). 